\title{
Protein and carbohydrate fractions of common vetch-oat mixtures depending on stage of growth and seeding rate in the mixtures
}

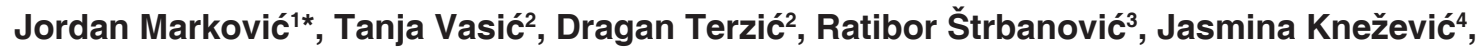 \\ Milomir Blagojevićs ${ }^{\text {, Đorđe Lazarević }}{ }^{1}$ \\ ${ }^{1}$ Institute for forage crops Kruševac, 37251 Globoder, Kruševac, R Serbia, ${ }^{2}$ University of Niš, Faculty of agriculture Kruševac, Kosančićeva \\ 4, 37000 Kruševac, $R$ Serbia, ${ }^{3}$ Institute for plant protection and environmental, Teodora Drajzera 9, 11040 Belgrade, $R$ Serbia, ${ }^{4}$ University of \\ Priština, Faculty of agriculture, Lešak, 38219 Lešak, R Serbia, ${ }^{5}$ Agricultural Combine "Zlatibor", 31315 Zlatibor, R Serbia
}

\section{A B S T R A C T}

\begin{abstract}
The production and utilization of intercropped legume- cereal bi-crops as ruminant feeds is beneficial for many reasons - legumes are rich in terms of protein concentration, whereas cereals are characterized by higher carbohydrate contents. To improve utilization of common vetch-oat mixtures as feed in Serbia, the objective of this investigation was to evaluate the crude protein (CP) and carbohydrate (CHO) fractions in these feeds using the Cornell Net Carbohydrate and Protein System (CNCPS) depending on the stage of plant development and seeding rate of common vetch and oat in the mixtures. The experiment was conducted at the experimental field of Institute for forage crops, Kruševac - Serbia, in 2015. The field trial was arranged in a randomized block design with three replications. In this research, pure stands of common vetch and oat, and their seed mixtures (common vetch:oat $-1: 1.5 ; 1: 1$ and 1:0.5) were studied harvested at three different cutting stages: beginning of vetch flowering - $10 \%$ of flowering; forming the first pods on $2 / 3$ vetch plants and forming green seeds in $2 / 3$ pods. The samples were analyzed for protein and carbohydrate fractions according to CNCPS. Stage of growth affected significantly all carbohydrate and protein fractions, except unavailable PC fraction of crude protein which did not change with plant growth and development. The highest protein fraction was intermediately degraded $\mathrm{PB}_{2}$ fraction of crude protein. The highest carbohydrate fraction was available cell wall $-\mathrm{CB}_{3}$ fraction of carbohydrate. According to the results obtained in these investigations, it was concluded that common vetch-oat mixtures varied significantly with respect to their carbohydrate and protein fraction. Due to lower CC fraction, oat was superior feed in terms of total carbohydrates supply to ruminants. Among all investigated mixtures and pure stand of oat and common vetch, it could be conclude that mixture with 1:1 common vetch-oat rate was superior because of higher $\mathrm{CA}$ and $\mathrm{CB}_{3}$ fractions of total carbohydrate and the highest $\mathrm{PB}_{2}$ fraction of crude protein.
\end{abstract}

Keywords: Common vetch; Oat; Carbohydrate and protein fractions

\section{INTRODUCTION}

Common vetch (Vicia sativa L.) is an annual legume crop, rich in protein that is characterized by high nutritive value and digestibility (Karagić et al., 2011). It represent a significant plant species for forage production used as hay, haylage or silage (Seven and Cerci, 2006). However, due to its characteristic tendency to lie down, forage yield and quality start to decrease if it is sown as monocrop (Karagić et al., 2008, 2011). Because of all this, Ansar et al. (2010) recommended to sow it with winter-sown small grains such as oat (Avena sativa L.), wheat (Triticum sativum L.), barley (Hordeum vulgare L.) and triticale (Triticosecale Wittmack).
Caballero and Goicoechea (1986) suggested that oat was the most suitable companion cereal for vetch species, while Thomson et al. (1990) preferred barley, and Roberts et al. (1989) preferred wheat. Despite its relatively low crude protein content, oat is regarded as an important forage crop due to its high yields and high carbohydrate levels. Caballero et al. (1995) have shown oat to be the most suitable companion crop for common vetch and hairy vetch. The mixed cropping of annual legumes and cereals attract the attention of many researchers, primarily due to their high yields (Lithourgidis et al., 2006), reduced use of non-renewable resources through reduced $\mathrm{N}$ fertilizer use, improved soil fertility (Lopez-Bellido Garrido and

\footnotetext{
${ }^{*}$ Corresponding author:

Jordan Marković, Institute for forage crops, 0037251 Globoder, Kruševac, R Serbia, Phone: 0038137442583 ; Fax: 0038137441295.

E-mail: jordan.markovic@ikbks.com
} 
Lopez-Bellido, 2001), higher crude protein content and these mixtures are characterized by a good balance between energy and protein content (Umuna et al., 1995). One of the most significant advantages of using legume-cereal mixtures is more efficient utilization of nutrients, which is a consequence of a favorable ratio of fermentable carbohydrates and protein content (Ummuna et al., 1997, Erole et al., 2009).

The productivity of high-yielding cows largely depends on the amount of feed intake, as well as on the efficiency of digestion and metabolism (Karsli et al., 2005). In ruminant nutrition, balancing structural and nonstructural carbohydrates and protein is very important to reduce nutrient losses, such as nitrogen, which is very important in a sustainable production system. In the modern ruminant nutrition system, detaled data on the rate of degradation and the nature of fermentative processes of all nutrients are becoming increasingly important. Hence, a system including above factors will be the most scientific way of feed analysis (Das et al., 2015). The Cornell Net Carbohydrate and Protein System (CNCPS), as described by Fox et al. (1992) in order to minimize nitrogen losses imply knowledge of the essential degradable and nondegradable protein, as well as the necessary amounts of nitrogen for sufficient development of microorganisms in the rumen (Van Amburgh, 2007; Das et al., 2015). On the other hand, carbohydrates are important in animal nutrition because they are the main source of energy and usually make up $70-80 \%$ of ruminant meals. Balancing the appropriate level and type of non-structural and structural carbohydrates is one of the main challenges in formulating meals for certain species and categories of animals and are important for improving milk production and animal health (Zadeh and Moradikor, 2013). Carbohydrate fractions differ in ratio and extent of fermentation, and because of this the adequate carbohydrates content in the meals is of great importance for digestion in the rumen, for synthesis of microbial protein and for maintaining a stable level of fermentation (Nocek and Tamminga, 1991, Hall and Herejk, 2001).

Quantification of various crude protein and carbohydrate fractions has not been extensively conducted on annual legumes-cereal mixtures and specific data on common vetch-oat mixtures are not reported. The objective of this research was to establish the influence of each factors: the ratio of common vetch and oat in the mixtures and stage of plant development on the protein and carbohydrate fractions content. These data would be useful for optimizing and planning ruminant nutrition systems and diets.

\section{MATERIALS AND METHODS}

Common vetch and oat were grown in binary mixtures (Photograph 1) at the experimental field of the Institute for forage crops Kruševac - R Serbia (21ำ $19^{\prime} 35^{\prime \prime}$ E, $43^{\circ}$ $\left.34^{\prime} 58^{\prime \prime} \mathrm{N}\right)$. The study area was situated at altitude of 166 $\mathrm{m}$ above sea level in Central Serbia. Soil type was with an organic matter content of approximately $3.5 \%$ and a $\mathrm{pH}$ of 6.5 . The mean annual temperature and the total precipitation for the region were $11.3^{\circ} \mathrm{C}$ and $636 \mathrm{~mm}$, respectively. The research was conducted to determine the effects of seed rates in mixtures of common vetch + oat and cutting stages on the protein and carbohydrates fractions derived by the CNCPS (Cornell Net Carbohydrates and Protein System). The experiment was performed using three different cutting stages $\left[\mathrm{A}_{1}\right.$ - beginning of common vetch flowering $-10 \%$ of flowering, $\mathrm{A}_{2}$ - forming the first pods on 2/3 common vetch plants (Photograph 2) and $\mathrm{A}_{3}$ - forming green seeds in $2 / 3$ pods] and five different mixture rates of common vetch and oat crops $\left(B_{1}-100 \%\right.$ common vetch $+0 \%$ oat; $\mathrm{B}_{2}-0 \%$ common vetch $+100 \%$ oat; $\mathrm{B}_{3}$ - common vetch : oat $1: 1.5 ; \mathrm{B}_{4}$ - common vetch : oat $1: 1$ and $B_{5}$ - common vetch : oat $1: 0.5$ ).

The crude protein (CP) and carbohydrate (CHO) subfractions were partitioned according to the CNCPS (Sniffen et al., 1992).

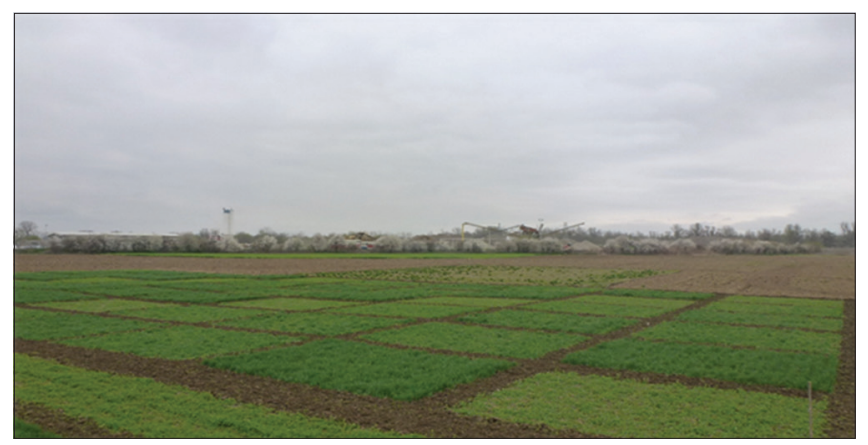

Photograph 1. Experimental field of common vetch and oat in binary mixtures.

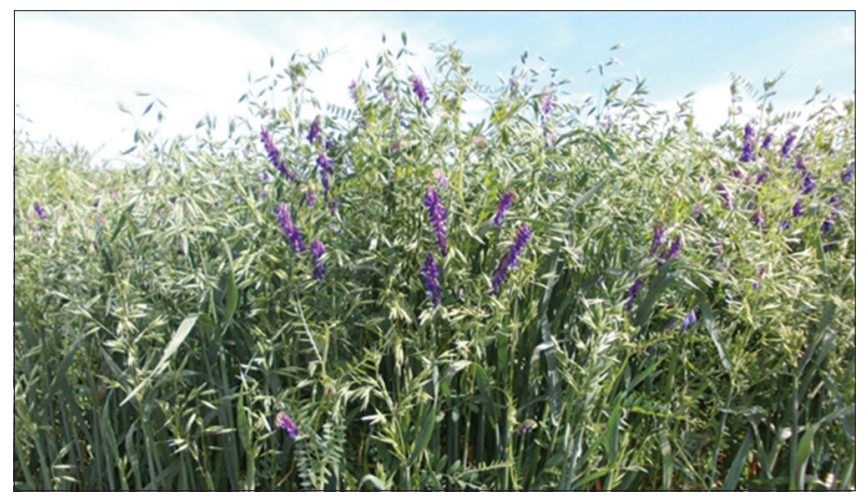

Photograph 2. Binary mixture of common vetch and oat at forming the first pods on $2 / 3$ common vetch plants. 
The characterization of the $\mathrm{CP}$ fractions as applied in this system are as follows: fraction PA is non-protein nitrogen (NPN), fraction PB is true protein (TP), and fraction PC is unavailable protein. Fraction $\mathrm{PB}$ is further divided into three fractions $\left(\mathrm{PB}_{1}, \mathrm{~PB}_{2} \mathrm{i} \mathrm{PB}_{3}\right)$ that are believed to have different rates of degradation in the rumen (Sniffen et al., 1992). The relative rumen degradation rates of the five protein fractions have been described as follows: fraction PA is rapidly degradable with an assumed degradation rate to be infinity, fraction $\mathrm{PB}_{1}$ is rapidly degradable with a degradation rate of $120 / 400 \% \mathrm{~h}^{-1}$, fraction $\mathrm{PB}_{2}$ is intermediately degradable possessing a degradation rate of $3-16 \% \mathrm{~h}^{-1}$, fraction $\mathrm{PB}_{3}$ is slowly degradable with a degradation rate of $0.06-0.55 \% \mathrm{~h}^{-1}$, and fraction $\mathrm{PC}$ is unavailable and considered to be undegradable.

The crude protein of samples was determined using Kjeldahl method. The NPN (Non-protein nitrogen), NDICP (Neutral detergent insoluble crude protein), ADICP (Acid detergent insoluble crude protein), SolP (Soluble protein), TP (true protein) and IP (Insoluble protein) were determined by Licitra et al. (1996).

The CNCPS crude protein fractions of the samples, PA, $\mathrm{PB}_{1}, \mathrm{~PB}_{2}, \mathrm{~PB}_{3}$ and $\mathrm{PC}$ were calculated based on $\mathrm{CP}, \mathrm{NPN}$, SolCP, NDICP, ADICP contents of samples according to Fox et al. (2004): PA = NPN; $\mathrm{PB}_{1}=$ SolCP - NPN; $\mathrm{PB}_{2}=\mathrm{CP}-\mathrm{SolCP}-\mathrm{NDICP} ; \mathrm{PB}_{3}=\mathrm{NDICP}-\mathrm{ADICP}$; $\mathrm{PC}^{2}=$ ADICP.

Where, PA refers to the non-protein nitrogen $\left(\mathrm{g} \mathrm{kg}^{-1} \mathrm{CP}\right)$; $\mathrm{PB}_{1}$, the rapidly degraded crude protein $\left(\mathrm{g} \mathrm{kg}^{-1} \mathrm{CP}\right) ; \mathrm{PB}_{2}$, the intermediately degraded crude protein $\left(\mathrm{g} \mathrm{kg}^{-1} \mathrm{CP}\right) ; \mathrm{PB}_{3}$, the slowly degraded crude protein $\left(\mathrm{g} \mathrm{kg}^{-1} \mathrm{CP}\right)$ and $\mathrm{PC}$, the bound and unavailable crude protein $\left(\mathrm{g} \mathrm{kg}^{-1} \mathrm{CP}\right)$.

Total carbohydrates $[\mathrm{CHO}=1000-(\mathrm{CP}+$ Ash + Ether extract)] and Non-Fiber carbohydrates $[\mathrm{NFC}=1000-$ (aNDF $+\mathrm{CP}+$ Ash + Ether extract $]$ were calculated according NRC (2001). Neutral detergent fiber (NDF, AOAC 2002.04) and Acid detergent fiber (ADF, AOAC 973.18) were determined as filter residue weights after boiling forage samples for $1 \mathrm{~h}$ in beakers either in neutral detergent solution supplemented with heat-stable $\alpha$-amylase, or in acid detergent solution, followed by vacuum filtration through a Whatman no. 54 filter paper and oven drying of the filter residue at $105^{\circ} \mathrm{C}$ for $2 \mathrm{~h}$ according to Van Soest et al. (1991). Acid detergent lignin was determined as the residue weight after soaking the ADF filter bag residue in sulphuric acid for $3 \mathrm{~h}$, followed by nine washes with water and oven drying of the filter bag residue at $105^{\circ} \mathrm{C}$ for $2 \mathrm{~h}$ (AOAC 973.18). NSC (Non-structural carbohydrates - monosaccharides and disaccharides) were determined as total ethanol soluble carbohydrates according procedures described by Hall et al. (1999), and starch content was determined according enzymathic method by Hall (2000).

Total carbohydrates $(\mathrm{CHO})$ are divided into five fractions: instantaneously solubilizable $\mathrm{CHO}$ composed mainly of simple sugars (CA, i.e. $\mathrm{NSC}, \mathrm{g} \mathrm{kg}^{-1} \mathrm{CHO}$ ); rapidly degradable $\mathrm{CHO}$ composed mainly of starch $\left(\mathrm{CB}_{1}\right.$, i.e. starch, $\mathrm{g} \mathrm{kg}^{-1}$ $\mathrm{CHO}$ ); intermediately degradable $\mathrm{CHO}$ composed mainly of soluble fibers such as pectic polysaccharides, $B$-glucans and fructans $\left(\mathrm{CB}_{2}\right.$, i.e. $\mathrm{NFC}-\mathrm{NSC}$ - starch, $\left.\mathrm{g} \mathrm{kg}^{-1} \mathrm{CHO}\right)$; slowly degradable $\mathrm{CHO}$ composed of available $\mathrm{NDF}\left(\mathrm{CB}_{3}\right.$, i.e. aNDF - CC, $\mathrm{g} \mathrm{kg}^{-1} \mathrm{CHO}$ ) and undegradable $\mathrm{CHO}$ (CC, i.e. aNDF x (Lignin / aNDF) x 2.4, $\mathrm{g} \mathrm{kg}^{-1} \mathrm{CHO}$ ) composed of completely undegradable NDF (Lanzas et al., 2007).

The experimental data were analyzed by a two-way factorial analysis using ANOVA with STATISTICA 6.0 for forage sample in a completely randomized design using a model that accounted for the main effects of stage of plant development and common vetch - oat mixtures. Effects were considered different based on significant $(p<0.05) F$ ratio. The significance of differences between arithmetic means was tested by Tukey test.

\section{RESULTS AND DISCUSSION}

Protein of forage legumes, particularly common vetch, are subject to rapid and extent degradation in the rumen. Efficient utilization of nutrients requires accurate degradation rate predictions of different feed fractions through the digestive tract. The CNCPS is based on the passage and degradation rate of each protein and carbohydrate fraction. Interactions of different feed components are considered for the maximum microbial production, reduction of nitrogen losses and determination of those nutrients that pass through the rumen undigested (Van Amburgh et al., 2007).

The protein fractions of common vetch - oat mixtures depending on the stage of growth and seeding rate of common vetch and oat in the mixtures are presented in the Table 1. The results of these investigations showed that PA fraction of crude protein increased from $473.4 \mathrm{~g} \mathrm{~kg}^{-1} \mathrm{CP}$ detected at flowering stage of growth to $496.5 \mathrm{~g} \mathrm{~kg}^{-1} \mathrm{CP}$ at the stage of growth characterized by forming the first pod on $2 / 3$ common vetch plants $(p<0.05)$. With the further growth and development the proportion of this crude protein fraction decreased to $448.9 \mathrm{~g} \mathrm{~kg}^{-1} \mathrm{CP}(\mathrm{p}<0.05)$. The highest content of PA fraction of $\mathrm{CP}$ was detected at the second stage of common vetch development. Across growing stages, the soluble fraction and fast degradable fraction of $\mathrm{CP}\left(\mathrm{PB}_{1}\right)$ had also the highest value at the 
Table 1: Protein fractions content of common vetch - oat mixtures depending on the stage of growth and common vetch seeding rate in the mixtures, $\mathrm{g} \mathrm{kg}^{-1} \mathrm{CP}$

\begin{tabular}{|c|c|c|c|c|c|c|}
\hline \multicolumn{2}{|c|}{ Treatments } & \multirow{2}{*}{$\begin{array}{c}\text { PA } \\
511.7^{b}\end{array}$} & \multirow{2}{*}{$\frac{\mathrm{PB}_{1}}{2.5^{\mathrm{c}}}$} & \multirow{2}{*}{$\frac{\mathrm{PB}_{2}}{341.5^{\mathrm{g}}}$} & \multirow{2}{*}{$\frac{\mathrm{PB}_{3}}{34.3^{\mathrm{abc}}}$} & \multirow{2}{*}{$\frac{\text { PC }}{109.9^{\text {cd }}}$} \\
\hline$A_{1}$ & $\mathrm{~B}_{1}$ & & & & & \\
\hline & $\mathrm{B}_{2}$ & $528.7^{b}$ & $0.4^{c}$ & $340.3^{9}$ & $21.0^{\mathrm{bcd}}$ & $109.5^{\mathrm{cd}}$ \\
\hline & $\mathrm{B}_{3}$ & $438.7^{c}$ & $2.8^{c}$ & $406.4^{\text {de }}$ & $38.6^{a b c}$ & $113.4^{\text {cd }}$ \\
\hline & $\mathrm{B}_{4}$ & $438.2^{c}$ & $2.6^{c}$ & $398.8^{\mathrm{de}}$ & $41.7^{\mathrm{ab}}$ & $118.5^{\mathrm{bc}}$ \\
\hline & $\mathrm{B}_{5}$ & $449.8^{d}$ & $2.8^{c}$ & $392.4^{\mathrm{e}}$ & $35.7^{a b c}$ & $119.3^{\mathrm{bc}}$ \\
\hline \multicolumn{2}{|c|}{$\overline{\mathrm{X}} \mathrm{A}_{1}$} & $473.4^{\mathrm{B}}$ & $2.2^{\mathrm{C}}$ & $375.9^{\mathrm{B}}$ & $34.3^{\mathrm{A}}$ & $114.1^{\mathrm{NS}}$ \\
\hline \multirow[t]{5}{*}{$A_{2}$} & $\mathrm{~B}_{1}$ & $517.7^{b}$ & $10.5^{\mathrm{a}}$ & $350.4^{\mathrm{fg}}$ & $19.4^{\mathrm{cd}}$ & $102.0^{\text {de }}$ \\
\hline & $\mathrm{B}_{2}$ & $552.1^{\mathrm{a}}$ & $8.0^{\mathrm{b}}$ & $293.7^{\mathrm{h}}$ & $49.5^{\mathrm{a}}$ & $96.7^{e}$ \\
\hline & $\mathrm{B}_{3}$ & $464.2^{c}$ & $11.8^{\mathrm{a}}$ & $369.9^{f}$ & $22.3^{b c}$ & $131.6^{a}$ \\
\hline & $\mathrm{B}_{4}$ & $436.7^{\text {ef }}$ & $7.5^{\mathrm{ab}}$ & $392.5^{\mathrm{e}}$ & $36.0^{\mathrm{ab}}$ & $127.1^{\mathrm{ab}}$ \\
\hline & $\mathrm{B}_{5}$ & $511.6^{b}$ & $6.4^{\mathrm{ab}}$ & $343.8^{g}$ & $24.9^{b c}$ & $113.1^{\text {cd }}$ \\
\hline \multicolumn{2}{|c|}{$\overline{\mathrm{X}} \mathrm{A}_{2}$} & $496.5^{\mathrm{A}}$ & $8.8^{A}$ & $350.1^{c}$ & $30.4^{\mathrm{AB}}$ & $114.1^{\mathrm{NS}}$ \\
\hline \multirow[t]{5}{*}{$\mathrm{A}_{3}$} & $\mathrm{~B}_{1}$ & $430.0^{\text {ef }}$ & $6.5^{\mathrm{ab}}$ & $426.8^{\mathrm{ab}}$ & $20.7^{\mathrm{bc}}$ & $115.9^{\mathrm{bc}}$ \\
\hline & $\mathrm{B}_{2}$ & $515.9^{b}$ & $3.5^{b c}$ & $365.8^{f}$ & $12.8^{d}$ & $102.4^{\text {de }}$ \\
\hline & $\mathrm{B}_{3}$ & $445.4^{\mathrm{de}}$ & $2.5^{\mathrm{bc}}$ & $417.5^{\mathrm{bc}}$ & $27.6^{\mathrm{abc}}$ & $106.9^{\text {cd }}$ \\
\hline & $\mathrm{B}_{4}$ & $419.8^{f}$ & $3.6^{b c}$ & $438.6^{a}$ & $21.4^{b c}$ & $111.1^{\mathrm{cd}}$ \\
\hline & $\mathrm{B}_{5}$ & $433.4^{\mathrm{ef}}$ & $7.6^{\mathrm{ab}}$ & $427.4^{\mathrm{ab}}$ & $24.6^{\mathrm{bc}}$ & $106.9^{c d}$ \\
\hline \multicolumn{2}{|c|}{$\overline{\mathrm{X}} \mathrm{A}_{3}$} & $448.9^{C}$ & $4.7^{B}$ & $415.3^{A}$ & $21.5^{\mathrm{B}}$ & $109.5^{\mathrm{NS}}$ \\
\hline \multicolumn{2}{|c|}{$\overline{\mathrm{X}} \mathrm{B}_{1}$} & $486.5^{\mathrm{B}}$ & $6.5^{\mathrm{NS}}$ & $372.9^{C}$ & $24.8^{\mathrm{NS}}$ & $109.2^{\mathrm{BC}}$ \\
\hline \multicolumn{2}{|c|}{$\overline{\mathrm{X}} \mathrm{B}_{2}$} & $532.2^{\mathrm{A}}$ & $3.9^{\mathrm{NS}}$ & $333.3^{\mathrm{D}}$ & $27.7^{\mathrm{NS}}$ & $102.8^{\mathrm{C}}$ \\
\hline \multicolumn{2}{|c|}{$\overline{\mathrm{X}} \mathrm{B}_{3}$} & $449.5^{\mathrm{D}}$ & $5.7^{\mathrm{NS}}$ & $397.9^{\mathrm{B}}$ & $29.5^{\mathrm{NS}}$ & $117.3^{\mathrm{A}}$ \\
\hline \multicolumn{2}{|c|}{$\overline{\mathrm{X}} \mathrm{B}_{4}$} & $431.6^{\mathrm{E}}$ & $4.6^{\mathrm{NS}}$ & $410.2^{\mathrm{A}}$ & $33.1^{\mathrm{NS}}$ & $120.4^{\mathrm{A}}$ \\
\hline \multicolumn{2}{|c|}{$\overline{\mathrm{X}} \mathrm{B}_{5}$} & $464.9^{c}$ & $5.6^{\mathrm{NS}}$ & $387.8^{\mathrm{B}}$ & $28.4^{\mathrm{NS}}$ & $113.2^{\mathrm{AB}}$ \\
\hline
\end{tabular}

PA-non-protein nitrogen, completely degraded in the rumen; $\mathrm{PB}_{1}$-the rapidly degraded crude protein; $\mathrm{PB}_{2}$-intermediately degraded crude protein; $\mathrm{PB}_{3}$-the slowly degraded crude protein; $\mathrm{PC}$-the bound and unavailable crude protein; $A_{1}$-beginning of common vetch flowering- $10 \%$ of flowering; $A$-forming the first pods on $2 / 3$ common vetch plants; $A$-forming green seeds on $2 / 3$ pods; $B_{1}-100 \%$ common vetch $+0 \%$ oat; $B_{2}-0 \%$ common vetch $+100 \%$ oat; $B_{3}$-common vetch-oat 1:1.5; $B_{4}$-common vetch - oat 1:1; B -common vetch-oat 1:0.5; *Values denoted by the same letter are not significantly different according to Tukey's protected LSD values; $\mathrm{LSD}_{0.05}$-least significant difference at $\mathrm{P}<0.05$

second stage of growth. Maturity of common vetch had the same effects on fraction $\mathrm{PA}$ and $\mathrm{PB}_{1}$, but despite the higher PA content at the first stage of growth than at the third stage of growth, $\mathrm{PB}_{1}$ content was lower at the first stage than at the third stage of common vetch growth $(\mathrm{p}<0.05)$. Alzueta et al. (2001) indicated that development stage of common vetch had contrasting effects on PA and $\mathrm{PB}_{1}$ fractions - fraction $\mathrm{PA}$ decreased and fraction $\mathrm{PB}_{1}$ increased. These authors reported that the soluble $\mathrm{CP}$ changed little with growth and development. The changes in $\mathrm{PA}$ and $\mathrm{PB}_{1}$ fractions could be explained by the accumulation and distribution of $\mathrm{CP}$ during the period of rapid seed growth. Caballero et al. (1998) indicated that during rapid seed growth most $\mathrm{CP}$ accumulated in the seed and CP was redistributed from vegetative plant parts. The trend obtained in this investigation could be explained by the sowing common vetch in mixture with oat. Results presented in the Table 1 showed that maturity of common vetch had contrast in effects on soluble fractions $\left(\mathrm{PA}\right.$ and $\mathrm{PB}_{1}$ ) and fraction $\mathrm{PB}_{2}$. The $\mathrm{PB}_{2}$ fraction of crude protein had the highest value of true protein, and during the period of investigation, fraction $\mathrm{PB}_{2}$ decreased $(p<0.05)$ from flowering to forming the first pod on $2 / 3$ common vetch plants. After that, with plant maturation, content of $\mathrm{PB}_{2}$ fraction increased. Those results could be explained by the fact that CP content is higher in the seed than in the vegetative plant parts. The neutral detergent insoluble fraction $\left(\mathrm{PB}_{3}\right)$ contributed little to total $\mathrm{CP}$ of investigated common vetch - oat mixtures. With plant growth and development, content of this fraction ranged from $34.3 \mathrm{~g} \mathrm{~kg}^{-1} \mathrm{CP}$ at the flowering stage of growth to $21.5 \mathrm{~g} \mathrm{~kg}^{-1} \mathrm{CP}$ at the forming the green seeds in $2 / 3$ pods $(\mathrm{p}<0.05)$. These results for fraction $\mathrm{PB}_{3}$ disagreed with results reported by Caballero et al. (2001). These authors concluded that as seed makes a larger fraction of total forage, a higher proportion of soluble true protein is accumulated in the seed as compared with non-protein nitrogen (NPN) or that some NPN of vegetative plant parts is redistributed as true protein to the seed. According to these authors, the proportion of fraction $\mathrm{PB}_{3}$ in the whole forage was lower at flowering than during the period of rapid seed development. Plant maturity did not have a significant effect on PC fraction, and the values for this fraction were the same at the first and second development stage, and changed very little from the second to the third stage of growth.

The solubility and degradability of protein, as well as the representation of individual fractions in common vetchoat mixtures depending on the common vetch ratio in the mixtures are presented in the Table 1. Statistical analysis showed that the common vetch-oat ratios in investigated mixtures were not significantly affected the $\mathrm{PB}_{1}$ and $\mathrm{PB}_{3}$ protein fractions $(\mathrm{p}>0.05)$. The highest $\mathrm{PA}$ content was recorded in the pure oat $\left(532.2 \mathrm{~g} \mathrm{~kg}^{-1} \mathrm{CP}\right)$, and mixture with common vetch - oat ratio $0.5: 1$ had the highest content of this CP fraction. In all other treatments of the current study, the PA fraction averaged below $500 \mathrm{~g} \mathrm{~kg}^{-1} \mathrm{CP}$, and ranged from $486 \mathrm{gkg}^{-1} \mathrm{CP}$ in the pure common vetch to $431.6 \mathrm{~g} \mathrm{~kg}^{-1} \mathrm{CP}$ in the mixture with common vetch - oat 1 : 1 ratio $(p<0.05)$. The highest true protein fraction $-\mathrm{PB}_{2}$ was determined in all investigated treatments, ranged from $410.2 \mathrm{~g} \mathrm{~kg}^{-1} \mathrm{CP}$ in mixture with $1: 1$ common vetch - oat to $333.3 \mathrm{~g} \mathrm{~kg}^{-1} \mathrm{CP}$ in pure oat. Unavailable PC fraction represent bound protein that is not degraded in the rumen and is not digested in the small intestine. The lowest content of PC fraction was detected in the pure oat $\left(102.8 \mathrm{~g} \mathrm{~kg}^{-1}\right.$ $\mathrm{CP})$, and the highest in the mixture with common vetch oat mixture $1: 1\left(120.4 \mathrm{~g} \mathrm{~kg}^{-1} \mathrm{CP}\right)$. In the other mixtures PC fraction was lower, but differences between treatments were not significant.

The concentrations of nonstructural and structural fractions of carbohydrates in feeds play a major role in the estimation of the energy value of feeds (NRC, 
2001). With the importance of carbohydrates in the diet, meauserement of the different carbohydrates fractions in feeds and diets is critical for diet formulation and relating diet and intake to animal performance (Eastrige, 2007). Contents of different carbohydrates fractions in common vetch-oat mixtures depending on the stage of growth and seeding rate of common vetch and oat in the mixtures are presented in the Table 2.

Across growing stages, the soluble and instantaneously degradable CA fraction of carbohydrates did not changed from beginning of common vetch flowering to forming the first pods on $2 / 3$ common vetch plants. But, with advancing maturity, content of this $\mathrm{CHO}$ fraction decreased by $39.6 \%$ (Table 2). Caballero et al. (2001) also found that CA fraction of $\mathrm{CHO}$ decreased in fresh common vetch forage with advancing maturity stages. Stage of growth had the same effect on the $\mathrm{CB}_{3}$ fraction of $\mathrm{CHO}$, which represents available cell wall. $\mathrm{CB}_{3}$ content changed very little from the first to the second stage of plant development, and ranged

\begin{tabular}{|c|c|c|c|c|c|c|}
\hline \multicolumn{2}{|c|}{ Treatments } & \multirow{2}{*}{$\frac{\text { CA }}{122.5^{\circ}}$} & \multirow{2}{*}{\begin{tabular}{|c|}
$\mathrm{CB}_{1}$ \\
$74.1^{\mathrm{b}}$
\end{tabular}} & \multirow{2}{*}{$\begin{array}{c}\mathrm{CB}_{2} \\
320.6^{\mathrm{a}}\end{array}$} & \multirow{2}{*}{$\begin{array}{c}\mathrm{CB}_{3} \\
271.5^{\dagger}\end{array}$} & \multirow{2}{*}{$\begin{array}{c}\text { CC } \\
211.2^{\circ}\end{array}$} \\
\hline$A_{1}$ & $\mathrm{~B}_{1}$ & & & & & \\
\hline & $\mathrm{B}_{2}$ & $165.0^{c}$ & $58.7^{\dagger}$ & $162.3^{c}$ & $466.8^{a}$ & $147.1^{\mathrm{g}}$ \\
\hline & $\mathrm{B}_{3}$ & $203.2^{\mathrm{b}}$ & $66.4^{d}$ & $174.8^{d}$ & $373.7^{b}$ & $181.9^{f}$ \\
\hline & $\mathrm{B}_{4}$ & $263.1^{\mathrm{a}}$ & $73.0^{b}$ & $121.9^{9}$ & $362.4^{d}$ & $179.6^{f}$ \\
\hline & $\mathrm{B}_{5}$ & $192.2^{b}$ & $72.6^{c}$ & $190.3^{d}$ & $337.2^{\text {cd }}$ & $207.6^{d}$ \\
\hline \multicolumn{2}{|l|}{$\bar{X} A_{1}$} & $189.1^{\mathrm{A}}$ & $68.9^{\mathrm{B}}$ & $194.0^{B}$ & $362.3^{A}$ & $185.5^{\mathrm{C}}$ \\
\hline \multirow[t]{5}{*}{$\mathrm{A}_{2}$} & $\mathrm{~B}_{1}$ & $161.0^{c}$ & $88.2^{a}$ & $187.9^{d}$ & $330.4^{d}$ & $232.6^{a}$ \\
\hline & $\mathrm{B}_{2}$ & $185.2^{\mathrm{b}}$ & $89.8^{a}$ & $77.9^{\mathrm{h}}$ & $452.3^{a}$ & $194.7^{e}$ \\
\hline & $\mathrm{B}_{3}$ & $170.9^{b}$ & $82.8^{\mathrm{ab}}$ & $167.2^{\mathrm{e}}$ & $360.3^{b}$ & $218.6^{c}$ \\
\hline & $\mathrm{B}_{4}$ & $213.3^{a}$ & $85.1^{a}$ & $143.5^{\dagger}$ & $352.8^{c}$ & $205.2^{\mathrm{d}}$ \\
\hline & $\mathrm{B}_{5}$ & $217.8^{a}$ & $75.6^{b}$ & $166.6^{e}$ & $328.1^{\mathrm{e}}$ & $211.9^{c}$ \\
\hline \multicolumn{2}{|l|}{$\bar{X} A_{2}$} & $189.6^{A}$ & $84.3^{A}$ & $148.6^{C}$ & $364.8^{A}$ & $212.6^{B}$ \\
\hline \multirow[t]{5}{*}{$\mathrm{A}_{3}$} & $\mathrm{~B}_{1}$ & $92.4^{\dagger}$ & $72.3^{c}$ & $342.5^{a}$ & $251.0^{\dagger}$ & $241.8^{a}$ \\
\hline & $\mathrm{B}_{2}$ & $145.1^{d}$ & $63.1^{\mathrm{e}}$ & $223.7^{c}$ & $352.0^{c}$ & $216.0^{\circ}$ \\
\hline & $\mathrm{B}_{3}$ & $123.7^{e}$ & $66.6^{d}$ & $277.5^{\mathrm{b}}$ & $319.8^{d}$ & $212.4^{c}$ \\
\hline & $\mathrm{B}_{4}$ & $128.1^{\mathrm{e}}$ & $63.4^{\mathrm{e}}$ & $275.5^{\mathrm{b}}$ & $304.7^{e}$ & $228.3^{b}$ \\
\hline & $\mathrm{B}_{5}$ & $82.6^{\dagger}$ & $68.6^{d}$ & $315.8^{a}$ & $308.7^{e}$ & $224.1^{\mathrm{b}}$ \\
\hline \multicolumn{2}{|c|}{$\bar{X} A_{3}$} & $114.4^{\mathrm{B}}$ & $66.8^{\mathrm{B}}$ & $287.0^{A}$ & $307.3^{\mathrm{B}}$ & $224.5^{\mathrm{A}}$ \\
\hline \multicolumn{2}{|l|}{$\overline{\mathrm{X}} \mathrm{B}_{1}$} & $125.3^{C}$ & $78.2^{\mathrm{A}}$ & $284.7^{\mathrm{A}}$ & $284.3^{\mathrm{D}}$ & $228.5^{\mathrm{A}}$ \\
\hline \multicolumn{2}{|l|}{$\overline{\mathrm{X}} \mathrm{B}_{2}$} & $165.1^{\mathrm{B}}$ & $70.5^{\mathrm{B}}$ & 154.6 & $423.7^{\mathrm{A}}$ & $185.9^{\mathrm{D}}$ \\
\hline \multicolumn{2}{|l|}{$\overline{\mathrm{X}} \mathrm{B}_{3}$} & $165.9^{\mathrm{B}}$ & $71.9^{\mathrm{B}}$ & $206.5^{\mathrm{C}}$ & $351.3^{\mathrm{B}}$ & $204.3^{C}$ \\
\hline \multicolumn{2}{|c|}{$\overline{\mathrm{X}} \mathrm{B}_{4}^{3}$} & $201.5^{\mathrm{A}}$ & $73.8^{A B}$ & $180.3^{D}$ & $340.0^{B}$ & $204.4^{\mathrm{C}}$ \\
\hline \multicolumn{2}{|l|}{$\overline{\mathrm{X}} \mathrm{B}_{5}$} & $164.2^{\mathrm{B}}$ & $72.3^{\mathrm{B}}$ & $224.5^{\mathrm{B}}$ & $324.6^{c}$ & $214.6^{\mathrm{B}}$ \\
\hline
\end{tabular}

CA-instantaneously solubilizable $\mathrm{CHO}$ composed mainly of simple sugars; $\mathrm{CB}_{1}$-rapidly degradable $\mathrm{CHO}$ composed mainly of starch; $\mathrm{CB}_{2}$-intermediately degradable $\mathrm{CHO}$ composed mainly of soluble fibers; $\mathrm{CB}_{3}$-slowly degradable $\mathrm{CHO}$ composed of available NDF; CC-undegradable $\mathrm{CHO} ; \mathrm{A}_{1}$-beginning of common vetch flowering-10\% of flowering; $A_{2}$-forming the first pods on $2 / 3$ common vetch plants; $A_{3}$-forming green seeds on $2 / 3$ pods; $B_{1}-100 \%$ common vetch $+0 \%$ oat; $B_{2}-0 \%$ common vetch $+100 \%$ oat; $B_{3}$-common vetch-oat $1: 1.5$; $\mathrm{B}_{4}$-common vetch-oat $1: 1 ; \mathrm{B}_{5}$-common vetch-oat 1:0.5; *Values denoted by the same letter are not significantly different according to Tukey's protected LSD values; LSD $_{0.05}$-least significant difference at $\mathrm{P}<0.05$ from 362.3 to $364.8 \mathrm{~g} \mathrm{~kg}^{-1} \mathrm{CHO}$. With advancing maturity stage, content of $\mathrm{CB}_{3}$ fraction decreased by $15.8 \%$, and at the third stage of plant growth was $307.3 \mathrm{~g} \mathrm{~kg}^{-1} \mathrm{CHO}$. Maturity of common vetch-oat mixtures had contrasting effects on fractions $\mathrm{CB}_{1}$ and $\mathrm{CB}_{2}$. Content of $\mathrm{CB}_{1}$ fraction increased from 68.9 to $84.3 \mathrm{~g} \mathrm{~kg}^{-1} \mathrm{CHO}$, and content of $\mathrm{CB}_{2}$ fraction decreased from 194.0 to $148.6 \mathrm{~g} \mathrm{~kg}^{-1} \mathrm{CHO}$ with plant development, from beginning of common vetch flowering to forming the first pods on $2 / 3$ common vetch plants $(\mathrm{p}<0.05)$. With advancing maturity, content of $\mathrm{CB}_{1}$ fraction decreased to $66.8 \mathrm{~g} \mathrm{~kg}^{-1} \mathrm{CHO}$, and content of $\mathrm{CB}_{2}$ fraction increased to $287.0 \mathrm{~g} \mathrm{~kg}^{-1} \mathrm{CHO}$. Seed proportion probably had the major effect on the contents of different $\mathrm{CHO}$ fractions. Unavailable $\mathrm{CC}$ fraction of $\mathrm{CHO}$ which is not degraded in the rumen and is not digested in the small intestine increased from 185.5 to $224.5 \mathrm{~g} \mathrm{~kg}^{-1} \mathrm{CHO}$ with plant growth and development. The majority of this fraction is lignin, which is completely undegraded and indigested.

When CNCPS CHO fractions of investigated common vetch-oat mixtures were interpretated, it was observed that pure sown oat contained higher CA fraction $\left(165 \mathrm{~g} \mathrm{~kg}^{-1}\right.$ $\mathrm{CHO})$ than pure sown common vetch $\left(125,3 \mathrm{~g} \mathrm{~kg}^{-1} \mathrm{CHO}\right)$ indicating that this feed was better source of fermentable $\mathrm{CHO}$ to ruminants. Results from this study indicated that the highest $\mathrm{CA}$ fraction of $\mathrm{CHO}$ was recorded in 1:1 common vetch-oat mixture. Concentration of $\mathrm{CB}_{1}$ fraction was the lowest, ranged from $70.5 \mathrm{~g} \mathrm{~kg}^{-1} \mathrm{CHO}$ in the pure sown oat to $78.2 \mathrm{~g} \mathrm{~kg}^{-1} \mathrm{CHO}$ in the pure sown common vetch. Depending on the composition of analyzed mixtures, the highest content of $\mathrm{CB}_{1}$ fraction was also recorded in 1:1 common vetch-oat mixture. Across common vetch-oat ratios in the mixtures, results showed that intermediately degraded $\mathrm{CB}_{2}$ fraction accounted from $284.7 \mathrm{~g} \mathrm{~kg}^{-1} \mathrm{CHO}$ in pure sown common vetch to $154.6 \mathrm{~g} \mathrm{~kg}^{-1} \mathrm{CHO}$ in pure sown oat. The highest ratio of common vetch in the investigated mixtures influenced the highest content of this $\mathrm{CHO}$ fraction. In typical ruminant diet, the $\mathrm{CB}_{3}$ fraction represent the available cell wall and the amount of this fraction is very important for meal formulation, especially in ruminant nutrition (Das et al., 2015). Pure sown common vetch contained the lowest $\mathrm{CB}_{3}$ fraction, and content of this fraction decreased from 351.3 to $324.6 \mathrm{~g} \mathrm{~kg}^{-1} \mathrm{CHO}$ with increasing common vetch proportion in common vetch-oat mixtures. Fraction CC is the lignin bound cell wall content of a feed, and this fraction is completely undigestible in the rumen. Das et al. (2015) found out in their previous investigations that feeds with low CC fraction was superior in terms of $\mathrm{CHO}$ supply to ruminants. On this aspect, forages like oat and mixtures which were higher in oat ratio were found to be better feeds for ruminants. 


\section{CONCLUSIONS}

These results illustrate that crude protein and carbohydrate fractions of common vetch - oat mixtures were affected by stage of growth and seeding rate of common vetch and oat in the mixtures. The $\mathrm{CP}$ fraction $\mathrm{B}_{2}$ presented the highest proportion of total insoluble $\mathrm{CP}\left(\mathrm{B}_{2}, \mathrm{~B}_{3}\right.$ and $\left.\mathrm{C}\right)$ at forming green seeds in $2 / 3$ common vetch pods, showing the advantage of delaying harvesting. The highest carbohydrate fraction was $\mathrm{CB}_{3}$ representing available cell wall, and the favorable relation between carbohydrate fractions was at forming the first pods on $2 / 3$ common vetch plants. So, our recommendation for harvesting common vetch - oat mixtures is after forming the first pods on $2 / 3$ common vetch plants. Pure sown oat had the highest PA content of $\mathrm{CP}$ and $\mathrm{CB}_{3}$ content of total carbohydrates. Regarding to the most favorable mixture depending on the seeding rate of common vetch and oat in the mixtures, our recommendation is $1: 1$ common vetch - oat mixture.

\section{ACKNOWLEDGEMENTS}

This research was supported by the Ministry of Education, Science and Technological development of Republic of Serbia.

\section{Authors' Contributions}

All the listed authors had participated in the manuscript. Dragan Terzić and Milomir Blagojević took part in establishing field experiment and collecting the samples. They also wrote the draft of the manuscript. Tanja Vasić took part in plant protection during this experiment. Jordan Marković did part of the lab experiment and helped in the interpretation of data. Ratibor Štrbanović, Jasmina Knežević and Đorđe Lazarević also helped in interpretation of data and proof reading of the final copy.

\section{REFERENCES}

Alzueta, C., R. Caballero, A. Rebolé, J. Treviňo, and A. Gil. 2001. Crude protein fractions in common vetch (Vicia sativa L.) fresh forage during pod filling. J. Anim. Sci. 79: 2449-2455.

Ansar, M., Z. I. Ahmed, M. A. Malik, M. Nadeem, A. Majeed and B. A. Rischkowsky. 2010. Forage yield and quality potential of winter cereal-vetch mixtures under rainfed conditions. Emir. J. Food Agric. 22(1): 25-36.

Caballero, C., C. Alzueta, L. T. Ortiz, M. L. Rodriguez, C. Barro and A. Rebolé. 2001. Carbohydrate and protein fractions of fresh and dried common vetch at three maturity stages. Agron. J. 93(5): 1006-1013.

Caballero, R., E. L. Goicoechea and P. J. Hernaiz. 1995. Forage yields and quality of common vetch and oat sown at varying seeding ratios and seeding rates of vetch. Field Crop Res. 41: 135-140.

Caballero, R. and E. L. Goicoechea. 1986. Utilization of winter cereals as companion crops for common vetch and hairy vetch.
In: F. M. Barba and J. M. Abreu (Eds.), Grasslands Facing the Energy Crisis. Proceeding of the Eleventh General Meeting of the European Grassland Federation. European Grassland Federation, Europe, pp. 379-384.

Das, L. K., S. S. Kundu, D. Kumar and C. Datt. 2015. Fractionation of carbohydrate and protein content of some forage feeds of ruminants for nutritive evaluation. Vet. World. 8(2): 197-202.

Eastridge, M. L. 2007. Advancements in feeding carbohydrates. WCDS Adv. Dairy Technol. 19: 63-74.

Erole, A., M. Kaplan and M. Kizilsimsek. 2009. Oats (Avena sativa L.)-common vetch (Vicia sativa L.) mixtures grown on a lowinput basis for a sustainable agriculture. Trop. Grasslands. 43: 191-196.

Fox, D. G., L. O. Tedeschi, T. P. Tylutki, J. B. Russell, M. E. Van Amburgh, L. E. Chase, A. N. Pell and T. R. Overton. 2004. The cornell net carbohydrate and protein system model for evaluating herd nutrition and nutrient excretion. Anim. Feed Sci. Technol. 112: 29-78.

Fox, D. G., C. J. Sniffen, J. D. O'Connor, J. B. Russel and P. J. Van Soest. 1992. A net carbohydrate and protein system for evaluating cattle diets. III Cattle requirements and diet adequacy. J. Anim. Sci. 70(11): 3578-3596.

Hall, M. B. and C. Herejk. 2001. Differences in yields of microbial crude protein from in vitro fermentation of carbohydrates. J. Dairy Sci. 84: 2486-2493.

Hall, M. B. 2000. Neutral detergent-soluble carbohydrates. In: Nutritional Relevance and Analysis. University of Florida Bulletin, United States, p. 339.

Hall, M. B., W. H. Hoover, J. P. Jennings and T. K. M. 1999. A method for partitioning neutral detergent soluble carbohydrates. J. Sci. Food Agric. 79: 2079-2086.

Karagić, Đ., S. Vasiljević, S. Katić, A. Mikić, D. Milić, B. Milošević and N. Dušanović. 2011. Yield and quality of winter common vetch (Vicia sativa L.) haylage depending on sowing method. Biotechn. Anim. Husb. 27(4): 1585-1594.

Karagić, Đ., S. Katić, V. Mihailović, S. Vasiljević, A. Mikić and D. Milić 2008. What a Seed Producer Need from a Plant Breeder. Abstarcts of the Second Grain Legumes Technology Transfer Platform (GL-TTP) Workshop, Novi Sad, pp. 56.

Karsli, M. A., H. Akdeniz, T. Levendoglu and Ö. Terzioglu. 2005. Evaluation of the nutrient content and protein fractions of four different common vetch varieties. Turk. J. Vet. Anim. Sci. 29: 1291-1297.

Lanzas, C., C. J. Sniffen, S. Seo, L. O. Tedeschi and D. G. Fox. 2007. A revised CNCPS feed carbohydrate fractions scheme for formulating rations for ruminants. Anim. Feed Sci. Technol. 136: 167-190

Licitra, G., T. M. Hernandez and P. J. Van Soest. 1996. Standardization of procedures for nitrogen fractionation of ruminant feeds. Anim. Feed Sci. Technol. 57: 347-358.

Lithourgidis, A. S., I. B. Vasilakoglou, K. V. Dhima, C. A. Dordasa and M. D. Yiakoulaki. 2006. Forage yield and quality of common vetch mixtures with oat and triticale in two seeding ratios. Field Crops Res. 99: 106-113.

Nocek, J. E. and S. Tamminga. 1991. Site of digestion of starch in the gastrointestinal tract of dairy cows and its effect on milk yield and composition. J. Dairy Sci. 74: 3598-3629.

NRC. 2001. Nutrient requirements of dairy cattle. $7^{\text {th }}$ ed. National Academy Press, Washington, DC, USA.

Roberts, C. A., K. J. Moore and K. D. Johnson. 1989. Forage quality and yield of wheat-vetch at different stages of maturity and vetch seeding rates. Agron. J. 81: 57-60. 
Seven, P. T. and I. H. Cerci. 2006. The effects on nutrient digestibility of hay and silages made in different conditions in lambs. Vet. Arh. 76(2): 111-117.

Sniffen, C. J., D. J. O'Connor, P. J. Van Soest, D. G. Fox and J. B. Russell. 1992. A net carbohydrate and protein system for evaluating cattle diets. II: Carbohydrate and protein availability. J. Anim. Sci. 70: 3562-3577.

Thomson, E. F., S. Rihawi and N. Nersoyan. 1990. Nutritive value and yields of some forage legumes and barley harvested as immature herbage, hay and straw in North-West Syria. Exp. Agric. 26: 49-56.
Van Amburgh, M. E., E. B. Reckttenwald, D. A. Ross, T. R. Overton and L. E. Chase. 2007. Achieving Better Nitrogen Efficiency in Lactating Dairy Cattle: Updating Field Usable Tools to Improve Nitrogen Efficiency. Proceedings of the Eighteenth Cornell Nutrition Conference, Syracuse, NY, pp. 25-38.

Van Soest, P. J., J. B. Robertson and B. A. Lewis. 1991. Methods for dietary fiber, NDF and non starch polysaccharides in relation to animal nutrition. J. Dairy Sci. 74: 3583-3597.

Zadeh, J. B. and Z. Moradikor. 2013. Ruminal protein degradation and estimation of rumen microbial protein production. Int. J. Adv. Biol. Biomedic. Res. 1(8): 914-921. 